Hispania Sacra, LXII

126, julio-diciembre 2010, 513-538, ISSN: 0018-215-X

\title{
ENTRE EL DIÁLOGO Y EL BELICISMO: DOS ACTITUDES ANTE EL TURCO DESDE EL OCCIDENTE A FINES DEL MEDIEVO*
}

\author{
POR \\ EMILIO Mitre FERNÁNDEZ \\ Universidad Complutense
}

\begin{abstract}
RESUMEN
Cuatro autores del siglo XV central, Nicolás de Cusa, Juan de Segovia, el humanista Eneas Silvio Piccolomini -Papa Pío II- y el rey bohemio Jorge Podiebrad, y otro de principios de la Edad Moderna -Erasmo de Rótterdam- muestran correctamente la reacción occidental frente a la presión del Imperio Otomano, desde la caída de Constantinopla en 1453 a la derrota de Hungría en Mohacs en 1526. Examinan dos formas de resolver el problema: el diálogo interreligioso que busca convertir a los turcos al cristianismo y luego legitimar la conquista, por ejemplo el pequeño libro de Nicolás de Cusa De pace fidei y, en parte, la Epistula ad Mahumetem de Pío II; y la creación de una gran alianza de los príncipes cristianos: vg. el proyecto paneuropeo de Jorge Podiebrad, inspirado en la vieja idea de cruzada.
\end{abstract}

Palabras ClaVE: Nicolás de Cusa, Juan de Segovia, Papa Pío II, Jorge Podiebrad, Erasmo de Rótterdam, Imperio Otomano, diálogo interreligioso, conversión cruzada, alianza de los príncipes cristianos.

\footnotetext{
* El presente trabajo desarrolla, considerablemente ampliada, la comunicación expuesta en Guerra y paz en la Edad Media. Seminario del Departamento de Historia Medieval de la Universidad Complutense 2, 3 y 4 de marzo de 2010, bajo el título «La paz entre cristianos y el síndrome turco a finales del Medievo: De Nicolás de Cusa a Erasmo de Rotterdam».
} 


\title{
BETWEEN DIALOGUE AND THE WAR: TWO POSITIONS ON THE TURKISH FROM THE WEST AT THE END OF THE MIDDLE AGES
}

\begin{abstract}
Four authors of XV central century (Nicholas of Cusa, Juan de Segovia, the humanist Eneas Silvio Piccolomini -pope Pio II- and the Bohemian King George Podiebrad) and another of the beginning of Modern Age (Erasmus of Rotterdam) show correctly the occidental reaction face to the Ottoman pressure, from the fall of Constantinople (1453) to the Hungarian defeat in Mohacs (1526). They consider two ways to solve the problem: the religious dialogue that leads Turkeys to convert to Christianism and then make legitimate their conquest, for example, the short work of Nicholas of Cusa De pace fidei, and partially the Epistula ad Mahumetem of Pius II), and the foundation of a great alliance of Christian princes: vg. the paneuropean project of George Podiebrad, inspired by the old idea of crusade.

KEY WORDS: Nicholas of Cusa, Juan de Segovia, Pope Pius II, George Podiebrad, Erasmus of Rotterdam, Ottoman Empire, interreligious dialogue, cross, conversion, alliance of Christian Princes.
\end{abstract}

Recibido/Received 20-03-2010

Aceptado/Accepted 16-06-2010

Una época considerada estructuralmente violenta como la Edad Media parece terreno propicio para el estudio de la guerra; uno de los fenómenos sociales más importantes en el devenir de la Historia en razón de su incidencia política, demográfica, psicológica, moral, literaria etc... Que la visión mas canónica de la sociedad medieval -la tripartición funcional- considerara necesaria una categoría (bellatores, pugnatores, defensores...) encargada de proteger todo el conjunto nos ahorraría muchos comentarios. ${ }^{1}$

Junto a la abundante literatura sobre la guerra se desarrollaría otra sobre la paz que, en el Bajo Medievo, tomaría especial cuerpo. Uno de los grandes especialistas del fenómeno guerra en esta época ha escrito: «De Dante a Wycliffe, de Marsilio de Padua y Pierre Dubois a Erasmo, pasando por Jorge Podiebrad rey de Bohemia, una esperanza constante, un proyecto tenaz aunque ilusorio, consistió en instaurar, bajo la responsabilidad de un poder único o de una asamblea soberana, una nueva comunidad cristiana en el interior de la cual la guerra

\footnotetext{
${ }^{1}$ E. Mitre y M. Alvira, «Ideología y guerra en los reinos de la España medieval», Revista de Historia Militar. Numero Extraordinario 2001,292. Sobre esa tripartición (aunque el estudio se limite fundamentalmente al período que discurre entre el siglo IX y los inicios del XIII) sigue siendo básica la obra de G. DubY: Les trois ordres ou l'imaginaire du féodalisme. París 1978.
}

Hispania Sacra, LXII

126, julio-diciembre 2010, 513-538, ISSN: 0018-215-X 
propiamente dicha sería desterrada de iure y desconocida de facto». A los testimonios de esos conocidos autores podrían sumarse otros como el Libro de la paz de Cristina de Pizan, la obra del mismo título de Georges Chastellain, ciertos sermones de Jean Gerson o la percepción de autores como Honoré Bovet quien recuerda las profundas diferencias entre quienes defendían la idea de guerra justa (opuesta a la paz injusta) y las gentes modestas que, lejos de perderse en este tipo de disquisiciones, sólo querían vivir en paz. ${ }^{2}$

\section{¿UNA NUEVA PERCEPCIÓN DEL PELIGRO BÉLICO?}

De acuerdo con la norma más convencional, los occidentales acostumbramos a considerar emblemática una fecha: 1453. Dos razones convergen en ello.

De una parte el que en ese año el ejército real francés venza a las fuerzas inglesas en Castillon liquidando con ello varios siglos de presencia británica en Guyena. Según las pautas mas académicas, se ponía fin así a la Guerra de los Cien años que enfrentó durante buena parte del Bajo Medievo a dos dinastías: los Capeto / Valois y los Plantagenet / Lancaster. La rivalidad anglo francesa, sin embargo, habrá de extenderse a lo largo de los siguientes siglos. ${ }^{3}$

1453 tiene también otro significado socialmente mucho más extendido: el de bisagra entre dos edades de la historia. La toma de Constantinopla por Mahomet II que pone fin a esa construcción política a la que habitualmente designamos con el nombre de Imperio Bizantino ${ }^{4}$ será un hecho capital en la secuencia de acontecimientos que van jalonando la expansión otomana. Entre ellos: la derrota serbia de Kossovo Polje (1389), el fracaso de la expedición de caballe-

\footnotetext{
2 P. Contamine, La guerre au Moyen Âge. París 1980, 463-464,

${ }^{3}$ Una cuestión planteada en Emilio Mitre, «La Guerra de los Cien Años: primer conflicto global en el espacio europeo» conferencia de apertura a Guerra y violencia en la Edad Media (VI coloquio del Centro de Historia del Crimen. Durango 6 de noviembre de 2008) Clio\&Crimen 5 (Durango 2008) 16-35.

${ }^{4}$ C. Cellarius fue el primer gran responsable de acotar el Medievo entre la fundación de Constantinopla y la caída de la ciudad en manos otomanas con su Historia medii aevi a temporibus Constantini Magni ad Constantinopolim a Turcis captam. Zeitz 1688. Un titulo del pasado siglo convertido ya en clásico sobre este último acontecimiento lo constituye el de S. Runciman, La caída de Constantinopla. Ed. española de Madrid 1973 sobre la versión inglesa de Cambridge 1965 (objeto de una reciente reedición con prólogo del conocido historiador de la guerra A. Beevor). Posteriormente los aportes sobre el tema han sido numerosos. Entre ellos vid. A. Pertusi, La caduta di Constantinopoli. Verona 1976, o la panorámica de M. CORTÉs ARRESE, «Imágenes de la caída de Constantinopla», Constantinopla 1453. Mitos y realidades, P. BÁdenAs de LA Peña e I. Pérez MarTín (Eds.). Madrid C.S.I.C. 2003, 469-478. En adelante, Constantinopla 1453... Sobre la personalidad del conquistador, otro clásico pleno de erudición es el de F. BABINGER, Mehmed der Eroberer und Seine Zeit. Munich 1953. Obra objeto de distintas ediciones y vertida a varias lenguas, en adelante por la edición inglesa Mehmed the Conqueror and his time. Princeton U. P. 1978.
} 
ros occidentales en Nicópolis (1396), la fugaz ocupación de Otranto por los otomanos (1480), la toma de Belgrado por éstos después de distintos intentos (1521) y, por último, la derrota de Luís II de Hungría en Mohacs (1526) que, en años posteriores, llegó a poner en peligro (1529 y 1683) la seguridad de la misma Viena.

En razón de una posible (y profunda) toma de conciencia sobre el peligro turco ¿Puede hablarse de un desplazamiento hacia Oriente de las inquietudes de las potencias europeas? Cabría mejor hablar de una disociación entre lo que es el sentir de ciertas minorías doctrinarias y lo que son las frecuentes actuaciones de esas potencias que -aun conscientes del peligro que se cernía en los Balcanes y el valle del Danubio- prolongan y aún amplían en la Modernidad viejas rivalidades mantenidas en escenarios del Occidente. De ahí el limitado alcance de una añeja aspiración: el establecimiento de la concordia entre los príncipes cristianos a fin de emprender en estrecha alianza la guerra (justa, se entiende) contra un enemigo exterior. ${ }^{5}$ Una derivación de ese negotium fidei et pacis que, desde siglos atrás, había nutrido la idea de cruzada. ${ }^{6}$

La confrontación Cristiandad Islam se ha considerado tradicionalmente como una de las constantes del Medievo. Inducciones muchas veces extraacadémicas han instalado una especial mala conciencia en nuestra sociedad: al margen de lo puramente conceptual, ni Reconquista ni Cruzadas pasan por su mejor momento en cuanto a popularidad social. Más allá de cualquier forma de palinodia, el efecto más positivo de ese fenómeno ha supuesto reforzar entre los profesionales del medievalismo el estudio de los contactos / choques entre sociedades apoyadas en diferentes credos religiosos. En consecuencia, las distintas formas de enfrentarse al otro. ${ }^{7}$

\footnotetext{
${ }^{5}$ Una voz irenista como la de Erasmo de Rotterdam lamentaba las querellas que enfrentaban a los príncipes cristianos más poderosos que ofrecían con ello un grato espectáculo a los turcos: «Mucho me cuesta persuadirme que exista turco tan truculento que mayores males impregne a los cristianos que los que ellos, cada cual a su vez, se inflingen a sí mismos». «Carta a Francisco I de Francia de 1 de diciembre de 1523» recogida en Educación del príncipe cristiano. Querella de la paz. Lorenzo RIBER (ed.). Barcelona 1985, 157.

${ }^{6}$ Entre los múltiples trabajos sobre el ideal de cruzada, vid. el reciente de J. FLoRI, La guerra santa. La formación de la idea de cruzada en el Occidente cristiano. Madrid-Granada, 2003. Una idea, como bien es sabido, extensible también al enfrentamiento ortodoxia-herejía. Entre otros trabajos al respecto puede consultarse uno colectivo con bastantes años de antigüedad pero aún útil VV.AA: Paix de Dieu et guerre sainte en Languedoc au XIII siècle, Toulouse, Cahiers de Fanjeaux 4, 1969.

${ }^{7}$ Para el caso del cristianismo-islamismo pueden consultarse entre otros títulos P. SENAC, L'ímage de l'autre. Histoire de l'occident médiéval face à l'islam, París 1983, R. BARKAI, Cristianos y musulmanes en la España medieval (el enemigo en el espejo), Madrid 1984. J. V. Tolan, Medieval Christian Perception of Islam. A Book of Essays, Londres 1996, R. FLETCHER, La cruz y la media luna. Las dramáticas relaciones entre el cristianismo y el Islam desde Mahoma a Isabel la Católica. Barcelona 2005, Emilio Mitre, Los credos medievales y el espejo de la herejía. Madrid 2006.
}

Hispania Sacra, LXII

126, julio-diciembre 2010, 513-538, ISSN: 0018-215-X 
En ese mundo tanto las afirmaciones categóricas, como las dudas y, por supuesto, las ambigüedades se encuentran repetidamente entrelazadas. Hablamos así de la dialéctica de las armas frente a la de las palabras cuando no -y ello será lo más frecuente- del difícil equilibrio entre belicismo e irenismo. ${ }^{8}$

En medio de esta vorágine, el conciliarismo actuará como factor de tensión añadido. Con él se relacionan prácticamente todos los autores a los que vamos a referirnos ya que, en mayor o menor grado o en algún momento de su vida, coquetearon con la idea del concilio universal como la máxima autoridad de la comunidad cristiana por encima de las veleidades papalistas. ${ }^{9}$ Casi todos ellos nacieron entre fines del XIV e inicios del XV. Erasmo de Rotterdam -la excepción- constituirá una suerte de estrambote.

\section{Nicolás de Cusa y Juan de Segovia ¿hacia la PaZ a través del diálogo ENTRE RELIGIONES?}

A caballo culturalmente entre el Medievo y el Renacimiento como otros conocidos autores, el cardenal Nicolás de Cusa (1401-1464), ${ }^{10}$ participó activamente en el concilio de Basilea defendiendo una reforma a fondo de la Iglesia. Con los años acabaría reconciliándose con la autoridad papal que le otorgó el capelo cardenalicio en 1448. Al servicio de Roma desempeñaría desde entonces una intensa actividad diplomática adobada de especiales reflexiones filosóficomorales. ${ }^{11}$ Esas circunstancias influirían poderosamente en su actitud ante varios problemas: los planteados por las diferencias entre Roma y Constantinopla y entre católicos y husitas centroeuropeos, pero también los derivados de la expansión otomana.

En la base filosófica de esa inquietud se sitúan dos obras: De Concordanthia catholica y De docta ignorantia escritas entre 1431 y 1440. De docta ignorantia parte de un principio: «a ningún hombre, por más estudioso que sea, le sobrevendrá nada más perfecto en la doctrina que saberse doctísimo en la ignorancia misma, la cual es propia de él. Y tanto más docto será cualquiera cuanto

\footnotetext{
${ }^{8}$ Sobre este último vid. P. BREZzI, «Spunti di irenismo e di ecumenismo dopo la cadutta di Constantinopoli (1453)», Saggi di storia medievale. Roma 1979, 175-185.

${ }^{9}$ Un clásico sobre el tema lo constituye B. TIERnEY, Foundations of the Conciliar Theory: Te contribution of the Medieval Canonists from Gratian to the Great Schism. Cambridge 1955. Una síntesis sobre el importante papel del conciliarismo en las turbulencias del Bajo Medievo se recoge en Emilio Mitre, Iglesia, herejía y vida política en la Europa Medieval. Madrid 2007, 128-137.

10 Sobre esta posición vid. E. Colomer, De la Edad Media al Renacimiento. Ramón Llull, Nicolás de Cusa, Juan Pico Della Mirandola. Barcelona 1975.

${ }^{11}$ Entre los muchos estudios sobre el Cusano, uno de los más recientes es el de K. FLAsCH, Nicolás de Cusa, Barcelona 2003.
} 
más se sepa ignorante». ${ }^{12} \mathrm{El}$ conocimiento humano sólo podía ser conjetural, aproximado o provisional por lo que la inteligencia humana no tenía capacidad para acceder a la Verdad última. De ahí que algunas autores hayan considerado que Nicolás de Cosa creyó que sólo se podía acceder a esa Verdad a través de una suerte de intuición mística. Ello implicaba que existían vías de acceso a la divinidad independientes de la confesión que se profesara. «Si un místico cristiano podía hallar a Dios ¿no podía hallarlo también un sufí musulmán?».13

A instancias de Pío II, quien deseaba reactivar el añejo expediente de la cruzada, Nicolás de Cusa escribió en 1461 un Cribratio Alkorani (Criba del Corán) que sin duda desconcertaría al pontífice. El cardenal venía a sostener que las doctrinas del Corán, estudiadas con el debido espíritu («cribado»), resultarían compatibles con las de la Iglesia tal y como se exponían en el Nuevo Testamento. Nada nuevo en el Cusano ya que unos años antes había redactado dos textos en una línea similar: La paz de la fe y la Carta a Juan de Segovia.

Nuestro autor escribe La paz de la fe (1453) impactado por «la divulgación de los crueles actos cometidos recientemente por el rey (sic) de los turcos en Constantinopla». ${ }^{14}$ Esa circunstancia, sin embargo, no le empuja ni mucho menos a incitar al uso de las armas frente a un peligroso rival, sino a fijar las bases para establecer un diálogo. Algunos autores de nuestro tiempo han hecho así de Nicolás de Cusa un adelantado de la tolerancia y el ecumenismo. ${ }^{15}$

En La paz de la fe, el «Verbo hecho carne, que tiene la primacía entre los habitantes del cielo», dialoga con algunos sabios (el indio, el tártaro, el persa, Pedro...) que simbolizan las semejanzas y diferencias entre las diversas opciones religiosas: «Avanzáis directamente hacia el propósito que pretendemos, porque todos vosotros, aunque os llamáis de distintas religiones, bajo toda esta diversidad, dais por supuesta una sola cosa que denomináis sabiduría. Pero decidme ¿acaso contiene la sola sabiduría todo lo que se puede decir?».16

Buceando en los arcanos de las distintas confesiones se llegará a la conclusión de que «no hay más que una sola religión en la diversidad de los ritos». Un consenso entre todos los hombres permitirá que la diversidad de religiones «sea

12 Nicolás de Cusa, La docta ignorancia, M. Fuentes Benot (ed), Barcelona 1984, 24. Con posterioridad (1449) el cardenal redactaría una Apología doctae ignorantiae

${ }^{13}$ Conclusiones a las que llega R. Fletcher: La cruz y la media luna... 155.

14 Nicolás de CUSA, «La paz de la fe», en la edición conjunta La paz de la Fe. Carta a Juan de Segovia, Víctor SANZ SANTA CRUZ (ed.), Madrid 1999 3. Interesante el estudio preliminar a cargo del editor de estos dos textos

15 A vueltas con este tema, M. de Gandillac, «Nicolas de Cues et l'œcuménisme», Revue d'Histoire Ecclésiastique, 67 (1972) 442-454, G. F. Vescovini, «L'irenismo di Niccolò Cusano», La tolleranza religios, en M. SinA (ed.), Milano, Vita e Pensiero. 1991, 27-55.

16 Nicolás de CuSA, «La paz de la fe», 12.

Hispania Sacra, LXII

126, julio-diciembre 2010, 513-538, ISSN: 0018-215-X 
armoniosamente reducida a una sola, que será en adelante inviolable». ${ }^{17}$ Concluye Nicolás de Cusa su obra con el Rey de reyes invitando a los sabios a que animen a sus países a «confluir con poderes de todos a Jerusalén, como centro común, para aceptar en nombre de todos una sola fe y firmar sobre ella la paz perpetua, a fin de que, en la paz, el creador de todas las cosas sea alabado y bendecido por todos los siglos. AMÉN».18 Una invitación en la que, puede pensarse, se mezcla la añeja idea de una renovada Jerusalén de signo celestial con una suerte de kantismo avant la lettre. ${ }^{19}$ No estamos, reconoce un especialista en la obra del Cusano, ni ante una posición sincrética ni ante la defensa de una religión de la razón. El cardenal «busca la unidad no en la estática uniformidad de lo idéntico sino en la coincidencia viviente de lo diverso».20

La paz de la fe guarda gran similitud con la respuesta del Cusano unos meses después (1454) a la misiva de su amigo el franciscano español Juan de Segovia.

En principio manifiesta el temor de que, al exacerbarse los enfrentamientos militares, se pueda materializar la máxima evangélica de que quien luche por la espada puede perecer también por ella (Mt. 26, 52). Nicolás de Cusa propone que, a través de los príncipes temporales (preferidos por los turcos mejor que los sacerdotes), se llegue a algún tipo de acuerdo. ${ }^{21}$

Este habría de basarse en un diálogo que, se confiaba, conduciría a la postre a los turcos a aceptar los principios básicos del credo cristiano. La admisión de la Santísima Trinidad podrían hacerla sobre la base de que «los sarracenos confiesan que Cristo es el verbo y el hijo de Dios y el 'ruholla' esto es, el espíritu de Dios». ${ }^{22}$ La existencia de un paraíso al modo cristiano podría ser también asumible ya que cabía pensar que las delicias de las que hablaba el Corán serían, al estilo propugnado por Avicena en su Metafísica, no tanto sensoriales como intelectuales. ${ }^{23}$ Quedarían dos cuestiones de difícil asunción por el Islam cual era la Cruz de la cual abominaban, y el sacramento de la eucaristía, aunque el Cusano no desespera de dar a la otra parte una explicación que le resulte razonable. ${ }^{24}$

\footnotetext{
17 Ibidem 7-9.

18 Ibidem 58.

19 Poco que ver, sin embargo, entre las bases de partida del Cusano y las del maestro de Königsberg. Este último considera que la paz perpetua es el resultado de la conjunción de los principios de la política interior y exterior apoyadas en fundamentos estrictamente laicos: la constitución civil republicana de los Estados; la federación de Estados libres y la hospitalidad universal que permite acoger sin hostilidad a todo extranjero. I. KAnT, Sobre la paz perpetua. Antonio TruYol y J. Abellán (eds.), Madrid $1991,15-30$

${ }^{20}$ E. Colomer, «Nicolás de Cusa, un pensador en la frontera de dos mundos», De la Edad Media al Renacimiento... 138.

${ }^{21}$ Nicolás de CuSA, «Carta a Juan de Segovia», La paz de la fe. Carta a Juan de Segovia... 62-65

22 Ibidem 66-67.

${ }^{23}$ Ibidem 68.

${ }^{24}$ Ibidem 68-69.
} 
La misiva concluye con una reiteración del cardenal en el valor de las virtudes del diálogo ante un conjunto de desgracias que, de acuerdo con una tradicional visión, cabía interpretar como pruebas enviadas por la divinidad frente a la tibieza que domina la Iglesia. «Yo creo firmísimamente que la persecución es permitida no para la muerte sino para la vida, no para suprimir la fe, sino para su exaltación, pues es propio de la Iglesia resplandecer bajo la persecución». ${ }^{25}$

El interlocutor epistolar del Cusano, Juan Alfonso González de Segovia, (más conocido como Juan de Segovia) nació en esta ciudad en 1393, fue profesor de Teología en la Universidad de Salamanca (e «ilustre por su discreción y sabiduría, puesto que igualaba en ciencia a los mas encumbrados teólogos» ${ }^{26}$ y delegado del monarca castellano en el Concilio de Basilea. Allí se manifestó como destacado defensor de la preeminencia conciliar; hasta el punto que se barajó su nombre en 1439, como sustituto de Eugenio IV, depuesto por los padres conciliares por trasladar las sesiones de Basilea a Ferrara. Apoyaría incluso al antipapa Félix V, elegido por el Concilio, que le designó cardenal en 1440. Liquidada la rebelión basilense bajo Nicolás V, Juan de Segovia acabó reconciliándose con la legítima autoridad papal que le compensó, por su desposesión del cardenalato, con el título de arzobispo de Cesarea. Moriría en 1458 legándonos, entre otras obras, la Historia gestorum generalis synodi Basiliensis, texto básico para conocer las peripecias de aquella turbulenta asamblea, y un breve tratado bajo el título Relatio super materia Bullarum de Praesidentia compuesto en 1434 a instancias de sus amigos conciliaristas. ${ }^{27}$

La actitud intelectual de Juan de Segovia ante el Islam ${ }^{28}$ es tema que también le acerca a las inquietudes de Nicolás de Cusa. De las tres posibles vías para la conversión de los musulmanes -la guerra abierta, el milagro y la predicación- opta abiertamente por la tercera. Ella sería posible merced a una paz

25 Ibidem 69-70.

${ }^{26}$ Eneas Silvio Piccolomini, La Europa de mi tiempo (1405-1458), F. Socas (ed.) Sevilla 1998, 173.

${ }_{27}$ Para el ambiente cultural en el que Juan de Segovia se mueve vid. las síntesis recogidas por M. AvILÉs, «La teología española en el siglo XV»,Historia de la Teología española, Melquíades ANDRÉs MARTín, (dir.), Madrid 1983, 511-516 y por Francisco Javier FERNÁNDEZ CONDE, «Los grandes problemas y realizaciones de la vida intelectual: Teología, espiritualidad, Filosofía, Derecho», La época del gótico en la cultura española (c. 1220-c. 1480) vol. XVI de Historia de España Ramón Menéndez Pidal, J. A. García de Cortázar (coord.), Madrid 1994. 437 y ss. Sobre Juan de Segovia conciliarista, vid. J. M. MARCH, «Sobre el Concilio de Basilea y Juan de Segovia» Estudios Eclesiásticos 7 (1928) 116-121; G. VerA-FAJARDo, La eclesiología de Juan de Segovia en la crisis conciliar (1435-1447), Roma 1968; y S. MADRIGAL, «Corpus Mysticum-Corpus politicum: primeros ecos de la crisis conciliar en la obra de Juan de Segovia», Iglesia de la Historia. Iglesia de la fe (Homenaje a Juan María Laboa), Madrid 2005, 67-298.

${ }^{28}$ Cuestión que cuenta con una monografía algo antigua pero de indudable valor, la de D. CABANELAS, Juan de Segovia y el problema islámico, Madrid 1952.

Hispania Sacra, LXII

126, julio-diciembre 2010, 513-538, ISSN: 0018-215-X 
duradera entre ambas partes, la intensificación de relaciones para superar prejuicios y la discusión doctrinal pacífica..$^{29}$

En esa creencia, Juan de Segovia impulsó una versión trilingüe del Corán (árabe, castellano y latín) para fomentar los puntos de contacto entre cristianos e islamitas ${ }^{30}$ Propuso también una conferencia con musulmanes ilustrados del reino de Granada; idea que cayó en saco roto tanto por la oposición de éstos como por el fuerte contrapeso ejercido en los medios castellanos por la «teología de cruzada». ${ }^{31}$ Trataría de retomar la iniciativa su discípulo Hernando de Talavera, primer arzobispo de Granada, pero fracasaría también por el celo de Cisneros que impuso la política de bautismos forzosos..$^{32}$

En resumen: El diálogo ínterconfesional propuesto por Nicolás de Cusa y Juan de Segovia como vía para una paz generalizada no era una iniciativa totalmente novedosa en el Occidente. Tiempo atrás lo habían impulsado personajes de la talla de Pedro el Venerable o Ramón Llull. El primero, promoviendo también una traducción del Corán al latín en viaje al Toledo de la llamada «Escuela de Traductores» hacia $1141 .{ }^{33}$ El segundo, en la línea marcada por las órdenes mendicantes, impulsando una labor misional entre los infieles. ${ }^{34}$

Pero el irenismo tenía sus límites. Bien porque el diálogo y la predicación suponían no tanto una sustitución del expediente de la cruzada como su com-

29 Ibid, 110-118.

30 Vid. el artículo también D. CABANELAS, «Juan de Segovia y el primer Alcorán trilingüe», Al-Andalus 14 (1949) 149-173.

${ }^{31}$ Espíritu que contaba, entre otros propagadores, con figuras de la talla de Fernando de Córdoba, Rodrigo Sánchez de Arévalo, Juan de Torquemada o Alonso de Espina. Vid. M. AviLÉs, «La teología española en el siglo XV», 526-527; V. CANTARINO, «Juan de Torquemada's Crusade against Islam», Religionsgesprache im Mittelalter. B. LewIS y F. NiEWOHNEN (eds), Wiesbaden 1992, 237-250. Para el clima cruzadista en estos años J. HANKIns, «Renaissance Crusaders: Humanist Crusade Literature in the Age of Mehmed II», Dumbarton Oaks Papers, 49 (1995) 111-207. Para el caso hispánico, hasta los inicios de la Modernidad, J. M. Floristán, «Los últimos Paleólogos, los reinos peninsulares y la cruzada», Constantinopla 1453... 247-296. Sobre la irregular recepción de la noticia de la caída de Constantinopla en España, mayor en la Corona de Aragón que en Castilla, vid. P. DíAz MAS, «El eco de la caída de Constantinopla en la literatura hispánica», ibidem 317-349.

32 R. FletCher, La cruz y la media luna... 154.

33 Vid. J. KRITZECK, Peter the Venerable and Islam. Princeton 1964 y el más reciente de D. IoGNA PRAT, Ordenner et exclure. Cluny et la societé chrétienne face á la hérésie, au judaïsme et à l'Islam. 1000-1150. París 1998. Cabría incluir también para esta época la figura de Pedro ABELARDO caso de que el filósofo del que nos habla en una de sus más populares obras fuera un musulmán. Cfr. Diálogo entre un filósofo, un judío y un cristiano, A. SAnjuán y M. Pujadas (eds.), Zaragoza 1988. Un reciente aporte sobre el dialogo entre religiones es el de José SÁNCHEZ HERRERO, «Dios es amor. Dios no puede más que amar» El discurso interreligioso entre la espada y la palabra, siglo X al XII», Estudios Trinitarios XLI/3 (Salamanca, Septiembre-Diciembre 2007) 581-648.

34 Para esta temática, uno de los grandes especialistas es J. RICHARD con obras como la compilación Croisés, missionnaires et voyageurs. Londres 1983. Sobre las influencias de Ramón en Cusa, vid. E. Colomer, De la Edad Media al Renacimiento... passim. 
plemento. Así lo entendió Pedro el Venerable quien pensaba que la condición imprescindible para combatir el Islam -reprobable por sí mismo- era conocerlo intelectualmente. ${ }^{35} \mathrm{Y}$ algo parecido cabe deducir de la lectura del prolífico Ramón Llull. 36

O bien porque el cristiano daba por hecho -y ¿no ocurría algo semejante en el otro lado?- que el diálogo entre credos incuestionablemente había de saldarse con el triunfo del propio ya que la razón y los argumentos más sólidos estaban de su parte. ${ }^{37}$ Resulta significativo, asimismo, que en el ocaso del Medievo muchos autores sigan midiendo al Islam por el rasero de las herejías. Se trata de un viejo cliché que le asimiló a una forma de arrianismo o una mezcla de los diferentes errores con los que la ortodoxia católica se había enfrentado desde siglos atrás ${ }^{38}$. La negación por los musulmanes de la divinidad de Cristo y la incomprensión del dogma trinitario en general facilitaba sin duda este tipo de simplificaciones.

El proyecto de Nicolás de Cusa que confiaba en superar estas diferencias, sin duda bien intencionado, pecaba de ingenuidad. Algo que se encontraría también en la Cribratio: «En su deseada unidad no le interesa combatir a los musulmanes, sino atraerlos al Evangelio. En el fondo de todo ello se esconde una gran confianza en la fuerza de convicción de la verdad cristiana». ${ }^{39}$ Por su parte, el muy irenista Juan de Segovia no tendría tampoco reparo en considerar infecciones arrianas y nestorianas los errores del Corán sobre la Trinidad y la Encarnación. ${ }^{40} \mathrm{Y}$ no dudaba que, por su incomprensión de la ley de Cristo, los musulmanes habían de ser considerados «herejes e incluso perfectos herejes». ${ }^{41}$

35 J. LE GoFf, Los intelectuales en la Edad Media. Barcelona 1986, 33.

36 Miguel Cruz Hernández, El pensamiento de Ramón Llull. Madrid 1977, 51 y ss. A. LiBERA, Pensar en la Edad Media. Barcelona 2000, 50-55. y Emilio MrTRE, Los credos medievales... 62-63. Junto a sus posiciones dialogantes -las del Llibre del Gentil e los tres savis de 1272, disputa razonada entre un cristiano, un judío y un sarraceno- Ramón Llull mantiene abierto el portillo del expediente cruzadista como recoge en algunos de sus escritos: la Segunda Parte, 2. de su pequeño tratado Libro de la orden de caballería, escrito hacia 1275; en el Lib. IV cap. LXXXVIII de su novela Blanquerna escrita entre 12821287; o en su obra de muy tradicional y significativo título, Petitio pro conversione infidelium et Recuperatione Terrae Sanctae, súplica al papa Bonifacio VIII de 1295. Vid. el completísimo Apéndice III bajo el título de «Bibliografía de Ramón Llull», en M. CRUZ HernándEZ: El pensamiento... 405 y ss.

${ }_{37}$ Desde la cristiandad oriental es interesante la controversia entre el basileus bizantino Manuel Paleólogo y un maestro persa musulmán en torno a 1394. Recientemente se ha vuelto a ella con motivo de la polémica desatada por el discurso de Benedicto XVI en Ratisbona el 26 de septiembre de 2006. El monarca denuncia, entre otras cosas, la falta de originalidad de Mahoma que se limita a plagiar descaradamente las prescripciones legales del judaísmo. Manuel PALEólogo, Diálogo con un musulmán (VII controversia) Ed. de J. J. Esparza y M. A. EsparZA. Barcelona 2006, 68.

${ }^{38} \mathrm{Cfr}$. Emilio Mitre, Los credos medievales, passim

${ }^{39}$ E. Colomer, «Nicolás de Cusa, un pensador», De la Edad Media al Renacimiento, 138.

40 Sumario del opúsculo «De mittendo gladio» recogido en D. CABANELAS, Juan de Segovia y el problema islámico, 266.

${ }^{41}$ En «Prólogo de Juan de Segovia a su Alcorán trilingüe» en ibid. 281. Eneas Silvio PiCCOLOMINI, al destacar la labor de Juan de Segovia como traductor del Corán dice que, con ello, «desentrañó sus

Hispania Sacra, LXII

126, julio-diciembre 2010, 513-538, ISSN: 0018-215-X 
EL PELIGRO TURCO INCENTIVO PARA PROYECTOS DE UNIDAD DE LOS PUEBLOS DE Europa: PÍO II y JoRge PODIEBRAd

Pocos papas como Pío II, Eneas Silvio Piccolomini antes de su elección, han despertado tanto interés en los medios académicos ${ }^{42} \mathrm{El}$ que nos haya legado en sus Comentarii un importante texto autobiográfico hace más atractivo aún al personaje. ${ }^{43}$ Nacido en las cercanías de Siena en 1405, presumió de haber tratado personalmente a cuatro papas: Martín V, Eugenio IV, Nicolás V y Calixto III. ${ }^{44}$ Condenados por el pueblo en vida y aclamados después de su muerte, Eneas considera oportuno legar a la posteridad una autobiografía -cuya redacción inició en 1462, dos años antes de morir- a fin de ser juzgado con la debida objetividad. 45

En su agitada vida de juventud y madurez alternó el estudio con aventuras amorosas y misiones diplomáticas. Manifestó, asimismo marcadas veleidades conciliaristas y, al igual que otros intelectuales de la época que compartieron esa posición, Piccolomini acabaría reconciliándose con el papado legítimo. Ello le permitiría en tan sólo doce años pasar del diaconado y presbiterado (1446) al arzobispado de Siena (1452), al cardenalato (1456) y al pontificado (1458) tomando el nombre de Pío II. Desde esa privilegiada posición derivaría en ardiente partidario de la autoridad romana tal y como resumiría en una palinódica frase: «Rechazad a Eneas, aceptad a Pio». Solicitaba con ello a los cristianos que no hiciesen caso de sus escritos de juventud y declaraba herética la doctrina que proclamaba la superioridad del concilio sobre el papa. ${ }^{46}$

El giro eclesiológico se acompañó de una abierta hostilidad hacia los turcos tras la caída de Constantinopla. Estos, escribe, habían convertido a los habitantes de la ciudad «en esclavos; contaminan con la aberración de Mahoma el celebre templo de Santa Sofía y todas las basílicas de la ciudad imperial». ${ }^{47} \mathrm{La}$ mi-

estupideces (de Mahoma) con razones y fundamentos tan bien fundados como realistas». La Europa de mi tiempo, 173.

${ }^{42}$ Entre la abundante bibliografía sobre el personaje se puede destacar G. PAPARELLI, Enea Silvio Piccolomini: Pio II. Bari 1950, B. Widmer, Enea Silvio Piccolomini Papst Pius II. Biographie und Ausgewahlte. Texte aus seinem Schriften Basilea-Stutgart 1963, A. ZIEGER, Enea Silvio Piccolomini (Pio II). Trento 1965, Ch. E. NAvILle, Enea Silvio Piccolomini: l'uomo, l'umanista, il pontifice. Locarno 1984, y las semblanzas de G. ARNaLdi, «Ritratto di Enea Silvio Piccolomini», Terzo Programma, Roma 3 (1965) 361-366 y de N. Ritchie, «Aeneas Silvius Piccolomini: Humanist and Pope», History Today 27 (1977) 434-444.

${ }^{43}$ Lo citaremos en adelante por la adaptación castellana bajo el título Así fui Papa, Antonio CASTRO ZAFRA (ed.), Madrid 1989

${ }^{44}$ De los tres últimos papas recoge semblanzas en La Europa de mi tiempo, 223-236.

${ }^{45}$ Pío II, Así fui papa... 13.

46 Ibidem 312.

47 Ibidem 120. 
litancia antiturca llegará a convertirse en toda una seña de identidad de su pontificado. 48

El sexto año de su gobierno de la Iglesia (1463) consideró que la situación política del Occidente era propicia para «cumplir mi voto y empunar las armas contra el Turco. Yo mismo presidiría una Cruzada para impedir la ruina de la Fe y el Evangelio: los dos supremos valores cuya defensa me fue encomendada al ser elegido Sumo Pontífice». ${ }^{49}$ La operación, sin embargo, se saldaría con un total fiasco ya que las promesas de colaboración de los príncipes quedaron en papel mojado. Cuando Pío II llegó anciano y enfermo al puerto de Ancona en donde pensaba reunir una sólida fuerza expedicionaria, se encontró con unos pocos millares de enfervorizados pero mal armados peregrinos y con las reservas de la república de Venecia que remoloneó a la hora de facilitar barcos para el transporte. Pío II murió sin que el sueño de una nueva cruzada pudiera materializarse; 50 un sueño que había de ser parejo al de un remozado liderazgo del Romano Pontífice sobre el conjunto de naciones del Occidente Europeo.

Esta circunstancia ha llevado a presentar a Piccolomini como una figura dentro de la historia del europeismo. Dos textos merecen en este caso especial atención.

Uno -citado ya- lo dedicará a referir «los acontecimientos dignos de mención y dignos a mi entender, de pasar a la posteridad, ocurridos en Europa».51 Los países de Europa de los que nos habla, aunque de una forma bastante irregular, ${ }^{52}$ son los que limitaban al oeste con el Atlántico y hacia Oriente con el Báltico y el curso bajo del Danubio. Los acontecimientos en buena medida están marcados por esa caída de Constantinopla que tanto le impactaría..$^{53}$ No sólo lamenta los daños causados a la vieja capital del Imperio Bizantino; también la desidia de los países del Occidente a la hora de socorrerla: «Nuestro reyes (¡Que vergüenza!) hicieron oídos sordos y cerraron sus ojos, sin darse cuenta de que si caía Grecia se derrumbaría la otra parte de la cristiandad -aunque más bien me inclino a creer que por estar ocupado cada cual en sus rencores y antipatías particulares, descuidaron el bien de todos». .54

\footnotetext{
48 J. HelmRath «Pius II und die Türken«, Europa und die Türken in der Renaissance, B. GuthmüLLER y W. KÜHLMANN (eds.), 2000, 79-137. La idea de poner en marcha una cruzada se la comunicó el pontífice en marzo de 1462 a un grupo de seis cardenales de su confianza. F. BABINGER, Mehmed the Conqueror... 233 y ss.

${ }^{49}$ Pío II, Así fui papa... 323 y ss.

${ }^{50}$ Antonio CAStro ZaFra, «Muerte en Ancona» Epílogo a Así fui papa ... 337-344.

${ }^{51}$ Eneas Silvio Piccolomini, La Europa de mi tiempo... 55.

52 A los estados hispánicos (los «cinco reinos») por ejemplo, dedica un reducido espacio, ibidem 183-187.

53 Ibidem 87-92. Sobre los horrores padecidos por la ciudad a su caída, volvería a insistir en Así fui papa, tal y como recogemos en nota. 43.

${ }^{54}$ La Europa de mi tiempo... 88.

Hispania Sacra, LXII

126, julio-diciembre 2010, 513-538, ISSN: 0018-215-X
} 
Una atmósfera de desquite, ha recordado recientemente un editor de esta obra, parece presidir La Europa de mi tiempo. Piccolomini puso al principio sus esperanzas en el emperador Federico III, que mostró escaso interés por el tema, acuciado por los problemas que le causaban sus vecinos polacos y húngaros. Más adelante la confianza se depositará en Alfonso V de Aragón, rey además de Nápoles desde 1442, de quien se hace un sentido panegírico al final de la obra. Muerto en 1458 (fecha en la que concluye la exposición de La Europa de mi tiempo) tan sólo quedaba confiar en el duque Felipe de Borgoña. ${ }^{55}$

El otro texto, considerado entre los más famosos de Piccolomini, es la Epistula ad Mahumetem, motivo de distintas especulaciones. ¿Fue teóricamente dirigida pero no llegó nunca a ser enviada por el pontífice al sultán otomano considerado en nuestros días como «una de las figuras más relevantes que ha producido la Edad Media»? ${ }^{56}$ ¿Sería el borrador para un posible acuerdo de paz? ¿Se intentaba con este texto hacer recapacitar a los príncipes cristianos sobre sus responsabilidades más que atemorizar al sultán? ¿Sería un mero ejercicio retórico que le convertiría en pieza de historia de la literatura más que de la historia política? ${ }^{57}$

Elucubraciones al margen, esta misiva gozó posteriormente de una extraordinaria difusión a través de distintas ediciones. El pontífice compendia en ella lo que fueron las posiciones de los intelectuales del Occidente de cara a la expansión turca ${ }^{58}$ En esencia, cabe reiterar, son dos las vías en juego ante este desafío.

\footnotetext{
55 F. SocAs, «Prólogo» a La Europa de mi tiempo... 38. Las distintas menciones a Alfonso V se rematan al final del texto con una recapitulación de sus logros que le convertían en «garante de la paz en Italia y dueño y árbitro de la situación en las Hispanias», ibidem 262.

56 F. BABINGER, Mehmed the Conqueror... 409.

${ }^{57}$ La misiva sería, así, «más una disertación que una carta», ibid. p. 199. Algunos autores interesados por los acontecimientos del momento y por el protagonismo de Pío II ni siquiera la citan. Sí lo hacen, por el contrario, con la supuesta carta enviada por el sultán a Nicolás V. S. RuNCIMAN, La caída de Constantinopla... 186. Para una evaluación de todas las posibilidades interpretativas de la carta de Pío II, Vid. Domingo F. SANZ, «Introducción» a la edición de la obra de Eneas Silvio PiccolOMINI, Epístola a Mehmet II. Madrid 2003, 11-25. Por esta versión la citaremos en adelante. Se ha destacado que, en los Comentarii, Pío II no hace referencia al envío de esta misiva. De haberla remitido no hubiera tenido nada de particular, ya que se daban algunos precedentes, aunque lo fueran en relación con los mongoles. como las cartas de Inocencio IV, de Urbano IV, de Juan XXII o de Benedicto XII entre 1245 y 1338. J. RichARD, Croisés, missionnaires et voyageurs, 259-262. Sobre la posibilidad de envío de la misiva se ha pronunciado recientemente B. WEBER, «Conversión, croisade et oecuménisme à la fin du Moyen-Âge: Encore sur la lettre de Pie II à Mehmed II», Crusades 7 (2008), Publisher by Ashgate for the Society for Study of the Crusades and the Latin East. 181-197.

58 Convergerían en este texto diversas tesis: la irenista que interpretaba alegóricamente el Corán y, en consecuencia, le consideraba compatible con la revelación cristiana; el recurso a las armas dentro de la ideología cruzadista; y la visión del Islam como instrumento sin valor intelectual pero útil para el gobierno del vulgo. L. D’AsciA, «El pontífice romano y el emperador troyano. La carta de Pío II (Eneas Silvio Piccolomini) a Mehmed II» en 'Ilu, 3 (1998) 7. Con posterioridad a esta fecha el mismo autor ha
} 
La irenista chocaría frontalmente con la idea de un Nicolás V (1447-1455) para quien Mahomet era una especie de precursor del Anticristo, comparable con el dragón rojo del Apocalipsis (Ap. 12,3) que tenia «siete cabezas, y diez cuernos y en las cabezas tenía siete diademas». ${ }^{59}$ Pío II trata, por el contrario, de convencer al sultán de la superioridad del cristianismo sobre el Islam ${ }^{60}$ por otras vías. Se usarán a su favor detallados y farragosos argumentos históricos, morales y teológicos.

Entre los primeros, la grandeza de los emperadores romanos cristianos y luego las de los carolingios y otónidas, amen de la brillantez de las hazañas de los caballeros occidentales en Tierra Santa.${ }^{61}$ Entre los argumentos morales estaba la superioridad de la felicidad espiritual ofrecida por el cristianismo (el cultivo del alma) frente a la felicidad puramente material (placeres corporales) brindada por el Islam; una dialéctica que conduce a que «Todos los doctos filósofos alaban la nuestra; a la tuya la desprecian». ${ }^{62}$ Los argumentos teológicos ofrecen una amplia batería que va del ensamblaje entre Antiguo y Nuevo Testamento en tanto el segundo complementa las predicciones del primero ${ }^{63}$ a un razonamiento del dogma trinitario. ${ }^{64}$ No puede faltar, por supuesto, lo que es común a todos los teólogos y polemistas católicos: la reprobación de Mahoma «hombre seguidor anteriormente de cultos idólatras, de escasa fortuna, de personalidad insolente... que sacó a la luz una tercera ley, formada por la antigua y la nueva, añadiendo numerosas estupideces de fuera». ${ }^{65}$

Según algunos mentores espirituales del Occidente, estos razonamientos forzosamente habían de desembocar en la claudicación de la otra parte. ${ }^{66}$ De ahí que, para terminar de ganarse al sultán, el papa le recomiende seguir el ejemplo tanto de los gobernantes del Bajo Imperio romano, como de aquellos reyes bárbaros que, desde el paganismo o desde el error arriano, acabaron adhiriéndose a la ortodoxia católica. ${ }^{67}$

publicado un libro bajo el título Il Corano e la tiara: l'epistola a Maometto di Enea Silvio Piccolomini, Bologna 2001.

${ }^{59}$ F. BABINGER, Mehmed the Conqueror... 121.

${ }^{60}$ Se ha jugado con el posible interés del sultán por la fe cristiana en cuyos rudimentos pudo ser instruido por su madre cristiana, ibidem 9 y 410.

${ }^{61}$ Eneas Silvio PicCOLOMini, Epístola a Mehmet... 143.

62 Ibidem 133.

${ }^{63}$ Ibidem 117-125.

${ }^{64}$ Ibidem 95 y ss, especialmente 101-105, 113-115, 141 o 185.

${ }^{65}$ Ibidem 165. Siguiendo las costumbres de los herejes, se dice, Mahoma «para engañar más fácilmente, mezclaba cosas malas y buenas», ibid. 167.

${ }^{66}$ L. VAlcke, Il De pace Fidei: Niccolò da Cusa e Enea Silvio Piccolomini» Pio II e la cultura del suo tempo, L. Rotonda SECCHI TARUGo (Ed.): Atti del primo convengo internazionale 1989, Milán, Istituto di Studi Umanistici F. Petrarca. Mentis Itinerarium, 1991, 301-312.

${ }^{67}$ Eneas Silvio Piccolomini, Epístola a Mehmet II... 65-67, citando especialmente los casos de Constantino y de Clodoveo. Este monarca franco fue considerado por los apologistas católicos como

Hispania Sacra, LXII

126, julio-diciembre 2010, 513-538, ISSN: 0018-215-X 
De fallar la vía del diálogo, Pío II plantea la del enfrentamiento armado, la cruzada en definitiva, de la que acabaría por ser, como hemos anticipado, un firme defensor. ${ }^{68}$ Para ello, recuerda a su oponente las cualidades de los pueblos con los que habría de enfrentarse caso de seguir con su política agresiva: «no te creemos tan ignorante de nuestra situación como para que no sepas cuán grande es el poder de la nación cristiana, cuán poderosa es España, cuán belicosa Francia, cuán populosa Alemania, cuán valerosa Inglaterra, cuán audaz Polonia, cuán fuerte Hungría, cuán decidida y experta en asuntos militares Italia. Sólo Hungría durante largo tiempo te sacó de quicio a ti y a tus progenitores. Desde hace ya ochenta años los estandartes turcos se enfrentan a los húngaros y permanecen clavados a las orillas del Sava y el Danubio. Una sola nación atormenta tus fuerzas. ¿Qué harías si tuvieras que tratar con los italianos, los franceses o los alemanes, enormes y poderosísimos pueblos?» 69

Es significativo que estos pueblos de acendradas virtudes militares estuvieran todos en comunión con la sede romana. Pío II podía contraponer, así, su solidez, a la debilidad de aquellos otros que iban sucumbiendo al empuje otomano y que, aún siendo también cristianos, se habían apartado como los griegos (bizantinos) «de la unidad de la Iglesia romana cuando tu invadiste Constantinopla, y aún no habían aceptado el decreto de Florencia y se mantenían en el error, no sintiéndose de acuerdo con la recta fe en lo referente al Espíritu Santo o al fuego del purgatorio». ${ }^{70} \mathrm{Su}$ caída en poder del sultán parecía una suerte de castigo por el pertinaz mantenimiento del cisma. A esas alturas (¿segundo semestre de 1461?) la política dialogante de Piccolomini hacia los cristianos de Oriente (o hacia los disidentes husitas de Centroeuropa, por no decir los propios musulmanes) parecía tan agotada como sus viejas veleidades conciliaristas.

una segunda versión del primer emperador romano cristiano. Cfr. Gregoire DE Tours, Histoire des francs. I. R. LATOUCHE (ed.), París 1963 (reimpresión de 1999) 120-121. Una visión crítica de esta conversión en I. N. WooD, «Gregorio de Tours y Clodoveo», La Edad Media a debate, L. K. LiTTLE y B. H. RosenweIn (Eds.), Madrid 2003, 125-153.

${ }^{68}$ Con anterioridad a la misiva a Mahomet, Pío II se había hecho propagandista de la cruzada a través de otros textos: La Oratio pro passaggio in Infidelibus de 1453, la Oratio de Constantinopolitana clade de 1454 y la Oratio habita in conventu Mantuano de 1459.L. D’AsCIA, «El pontífice romano y el emperador troyano»... 12. En la génesis doctrinal de la Epístola jugaría mucho sin duda el cardenal Juan de Torquemada con su Tractatus contra principales errores perfidi Mahumeti. ibidem 13 y 16-18.

${ }^{69}$ Eneas Silvio Piccolomini, Carta a Mehmet II... 49.

70 Ibidem 55. El papa se está refiriendo a unas diferencias entre las sedes de Roma y Constantinopla (primacía romana, procesiones del Espíritu Santo, eucaristía y purgatorio) que parecieron saldadas en 1439. Se trata del acuerdo firmado en el concilio de Florencia (prolongación papalista del mantenido por los rebeldes conciliares en Basilea) por Eugenio IV y los representantes del emperador bizantino. Acuerdo rechazado por buena parte del clero y la opinión pública orientales. 
Estricto coetáneo de Eneas Silvio Piccolomini lo será el noble checo Jorge Podiebrad (o Podebrady) (1420-1471) que vivió la resaca de la conmoción husita que sacudió Centroeuropa durante buena parte del siglo XV. ${ }^{71}$

La fase más áspera del husismo se desarrolló desde la ejecución del reformador Juan Hus en la hoguera de Constanza (1415) hasta la derrota del ala radical del movimiento (los taboritas) en Lipany en 1434; momento en que se abriría una suerte de «thermidor husita». Se intentó entonces aplicar un programa templado (establecido en los Compactata de 1436) a fin de permitir una convivencia pacífica entre católicos y husitas moderados: los utraquistas; así llamados por una de sus principales reivindicaciones cual era la extensión a los laicos (sub utraque specie) de la comunión bajo las dos especies. En ese contexto es en el que se movió el rey Jorge (el «rey de heréticos») ${ }^{72}$ elevado al trono bohemio por los suyos como una suerte de monarca nacional, en 1458..$^{73}$

Pese a su carácter contemporizador, las relaciones del monarca con Pío II no fueron buenas. La política de firmeza de éste frente al husismo en cualquiera de sus manifestaciones, similar a la adoptada frente al conciliarismo o los turcos, no facilitó la deseada reconciliación espiritual en Centroeuropa. ${ }^{74}$ En 1462 el pontífice rompió los Compactata, lo que facilitó el camino a su sucesor -Pablo II- para excomulgar al checo y lanzar contra él al monarca húngaro Matías Corvino quien se proclamó rey de Bohemia. Jorge Podiebrad, sin embargo, resistiría hasta su muerte en 1471. Legó su corona a la dinastía polaca de los Jagellón y a la posteridad un curioso proyecto de unidad europea bajo el título de Tratado de alianza y confederación entre el rey Luis XI, Jorge, rey de Bohemia y la señoría de Venecia para resistir al turco..$^{75}$ Paradójicamente coincidía de forma sustancial con las ideas europeístas defendidas por su rival Pío II.

El programa, redactado en torno a 1463 en colaboración con el comerciante grenoblés Antonio Marini, invocaba nostálgicamente en su preámbulo tiempos pasados en los que la cristiandad había sido «sumamente floreciente y dichosa tanto por su población como por su potencia; tal era su extensión que encerraba

\footnotetext{
${ }^{71}$ Entre la bibliografía vertida al castellano sobre el husismo se encuentra el libro de J. MACEK, $L a$ revolución husita. Orígenes, desarrollo y consecuencias, Madrid 1975.

72 La diferencia entre esos dos momentos del husismo la marcó F. G. HEYMANN con la redacción de dos obras: John Zizka and the Hussite Revolution, New York 1955 y George of Bohemia, King of Heretics, Princeton 1965.

${ }^{73}$ Desde la óptica de los historiadores del país, Jorge sería todo un restaurador del Estado checo. J. KEJR, Los husitas, Praga 1988, 110.

${ }^{74}$ La Historia Bohemica refleja bien la consideración que al papa le merecían los checos como pueblo culto pero inclinado a peligrosas innovaciones religiosas. Pío II, La historia de Bohemia en romance. Sevilla 1509 f. V v.

75 Pasajes destacados de este documento se recogen en la importante antología de D. de RouGEMONT, Tres milenios de Europa. Madrid 1963 74-79. Por ella citaremos en adelante.
}

Hispania Sacra, LXII

126, julio-diciembre 2010, 513-538, ISSN: 0018-215-X 
en su seno ciento diecisiete vastos reinos y sacó de ellos tantos pueblos que ocupó por mucho tiempo gran parte de los paganos al mismo tiempo que el sepulcro del Señor. No había entonces nación en el mundo entero que se atreviera a atacar la dominación de los cristianos. Ahora, por el contrario, vemos cómo todo está desgarrado, reducido, debilitado, despojado de todo su fulgor y de todo su esplendor de antaño... (el Islam y después los turcos han sobrevenido) reduciendo a su potencia primero el glorioso imperio de los griegos, después... deportando fuera de los países cristianos un número de almas casi infinito».76

La estructura europea propugnada se basaba en la idea de naciones tal y como se había procedido en los concilios bajomedievales. De entrada se contaba con una nación germana, otra francesa y otra italiana, aunque cabía la posibilidad de admitir (como en las asambleas conciliares) una hispana y otra británica. El concepto de nación era un tanto laxo ya que en el seno de cada una de ellas se admitía la posibilidad de estar representados los distintos estados que englobaban: la hispana los llamados «cinco reinos», Italia sus reinos y ciudades-estado, Francia el potente ducado de Borgoña, Alemania sus ducados y reinos circundantes, etc...77

Esa especie de sociedad de naciones avant la lettre dispondría de varios organismos.

Habría una Asamblea federal que se reuniría por primera vez en Basilea el domingo Reminiscere de 1464 presidida por un príncipe alemán, sin duda el emperador, durante un período de cinco años. El segundo quinquenio, la reunión sería en una ciudad de Francia a determinar, bajo la presidencia, se suponía, de Luís XI. El tercer quinquenio la Asamblea actuaría en Italia bajo la presidencia, presumiblemente, del dogo de Venecia dada la preeminencia naval de esta ciudad. De incorporarse España al proyecto se otorgaría un lugar preferente al rey de Castilla. A cada nación correspondería un voto, «pero si entre los embajadores de los reyes de una sola y misma nación son emitidos votos contrarios sobre cualquier asunto, decidimos que lo que fuera hecho y concluido por la mayoría será mantenido tan firmemente como si hubiese sido juzgado y acordado por unanimidad de esa nación...».78

Como «la paz no puede ser cultivada sin la justicia ni la justicia sin la paz» se crearía un tribunal o Consistorio con residencia en el lugar en que estuviese la Asamblea la cual fijaría las normas para su funcionamiento. Ese organismo solventaría las diferencias entre los integrantes de la confederación a los que, de

\footnotetext{
76 Ibidem 76.

77 F. G. Heymann, George of Bohemia... 293 y ss, en un capítulo bajo el título de «Grand design» con el que se define el proyecto del rey bohemio.

78 Recogido en D. De Rougemont, Tres milenios... 79. Algunas consideraciones en F. G. HeYMANN, George of Bohemia... 105.
} 
entrada, se les prohíbe ejercer la fuerza en la liquidación de sus contenciosos particulares. ${ }^{79}$

La paz entre príncipes cristianos era condición sine qua non para «defender y proteger la religión cristiana y a todos los fieles oprimidos contra el inmundo príncipe de los turcos».$^{80}$ De ahí la necesidad de una fuerza armada conjunta, esencialmente mercenaria, a sufragar a través de las tasas impuestas a los súbditos y de «los diezmos que son donados y vertidos a las iglesias y a los eclesiásticos y religiosos de nuestros reinos, principados y señoríos». ${ }^{81}$

Como ha advertido F. G. Heymann, el proyecto de Jorge Podiebrad no implica una secularización total de la idea de Europa..$^{82}$ Se invoca, en efecto, la «Cristiandad, gloria del universo» y el «honor de la divina majestad de la Santa Iglesia romana y de la fe católica»; 83 pero, del funcionamiento de la Asamblea se deduce que, frente al viejo liderazgo de Papado y Sacro Imperio, se apuesta por una realidad más acorde con los nuevos tiempos: la de unos embrionarios estados-nación. El proyecto se vio condenado al fracaso ya que Luis XI de Francia, de quien se esperaba fuera uno de sus principales valedores, manifestó sus reservas. Además, el papa Pablo II, abiertamente hostil al rey de Bohemia, anunció para contrarrestar su programa la fundación en 1470 de una Cofradía de Paz Universal que no obtuvo mayores resultados. ${ }^{84}$

En resumen: Al animar a los pueblos de Europa a limar asperezas y coaligarse contra el peligro musulmán Pío II contaba con claros precedentes. Uno de los mas cercanos lo facilitaba el poeta Eustaquio Deschamps quien a finales del siglo XIV decía: «Somos hermanos, un pueblo y una ley / que Jesucristo quiso ganar por su sangre / Pongámonos de acuerdo y emprendamos el camino / para conquistar de corazón Tierra Santa... Requiramos al rey de los francos y al de España / llamemos al de Aragón y al de Inglaterra / al Preste Juan, a los genoveses y a los venecianos, a Chipre, a Rodas, al rey / de Portugal, llamemos a Navarra / Papa y Emperador, aprestaos / para conquistar de corazón Tierra Santa». ${ }^{85} \mathrm{El}$ proyecto de Jorge Podiebrad, a su vez, tenía ciertas similitudes con el propugnado por Pierre Dubois siglo y medio atrás. ${ }^{86}$

\footnotetext{
${ }^{79}$ Recogido en D. de Rougemont, Tres milenios... 78.

${ }^{80}$ Ibidem 78.

${ }^{81}$ Ibidem 78 y F. G. Heymann, George of Bohemia... 107.

82 Ibidem 101.

${ }^{83}$ D. de Rougemont, Tres milenios... 76 y 78 respectivamente.

${ }^{84}$ B. VoYenne, Historia de la idea europea, Barcelona 1965, 63-64.

${ }^{85}$ Eustache Deschamps, Oeuvres complètes, Ed. de Queux de Saint-Hilaire. T. II. París 1878-1901,

${ }^{86}$ F. G. Heymann, George of Bohemia ... 301.
} 138-139. 
Sin embargo ¿Qué tenía más peso entre los estados del Occidente: La exaltación de los elementos comunes (o complementarios) a todos los príncipes cristianos o la expansión de sesgadas imágenes negativas del otro a fin de reforzar las virtudes y la identidad nacional propias? Caso de imponerse estas últimas se trabajaba indudablemente a contrapelo de una predicada paz generalizada en el conjunto del Occidente. Además, las cruzadas, que habían permitido conocerse mejor a los distintos príncipes y pueblos de Europa ¿no habían contribuido también con ese acercamiento a que se aborreciesen más a fondo unos a otros? ${ }^{87}$ Y, en relación con el Islam ¿No se anteponían frecuentemente los cálculos materiales a los ideales religiosos? ${ }^{98}$

Todo ello sin necesidad de extendernos en otro factor no desdeñable: la existencia de cierta corriente turcófila que se manifestaba de diferentes formas. Bien porque se considerara que los turcos, como herederos de los teucros (troyanos), hacían justicia por los pasados excesos de los griegos-aqueos (antepasados de los bizantinos) contra su ciudad ${ }^{89} \mathrm{O}$ bien porque se diera como bueno un poder secular (aunque como en este caso no fuera cristiano) dotado del derecho y el deber de intervenir para reformar la Iglesia limpiándola de todos los elementos corrompidos..$^{90}$ Desde un punto de vista pragmático, además, Mahomet II y sus herederos no se limitaron a conquistar por conquistar, sino a crear

\footnotetext{
${ }^{87}$ Muy conocida será la emulación suicida que en la Tercera Cruzada protagonizaron Ricardo Corazón de León y Felipe Augusto de Francia quienes trasladaron a Tierra Santa las rivalidades que les enzarzaban en sus países de origen. El historiador Jacques de Vitry recuerda que «sus resentimientos, sus odios y sus discordias llegaron a tal extremo» que se negaban la colaboración cada vez que uno de ellos emprendía acción militar contra una ciudad. Historia de las cruzadas. Nilda Guglielmi, (ed.) Buenos Aires 1991, 79

${ }^{88}$ Es famoso el proceso, precisamente en 1452, contra el conocido hombre de negocios francés Jacques Coeur acusado de tráfico fraudulento de armas con los sarracenos. P. AlPHANDERY y A. DUPRONT, La Cristiandad y el concepto de cruzada (II) Las cruzadas (siglos XII-XIII), México 1962. 172. Eneas Silvio Piccolomini recuerda que a la paz de Lodi suscrita entre las principales potencias italianas en 1454 se había llegado, entre otras razones, porque Venecia veía peligrar sus intereses mercantiles a causa de la guerra con el turco. La Europa de mi tiempo, 197. Mahomet II, por su parte, aunque convirtiese Santa Sofía en mezquita, reconoció al patriarca ortodoxo Genadio la posesión de la segunda de las grandes iglesias de la capital, la de los Santos Apóstoles. Asimismo, quedaron intactas, para los servicios religiosos normales, otras como la de Pammacaristos, la de San Demetrio, la de Peribleptos o la de San Jorge de los Cipreses. S. Runciman, La caída... 217.

${ }^{89}$ Ibidem 185-186.

${ }^{90}$ L. D’AsCiA: «El pontífice romano y el emperador troyano»... 22-23. Destaca el caso muy especial de Jorge de Trebisonda, cuyo anticlericalismo turcófilo le llevará a considerar a Mahomet II un nuevo Constantino. Vaticinios de raíz cristiana se aplicarían a los turcos como legítimos herederos del imperio de Bizancio por parte de otros autores como el helenista Ciriaco de Ancona que acompañó al sultán en su entrada en Constantinopla. J. GIL, «El fin del Imperio Bizantino y su proyección escatológica, en Constantinopla 1453, p. 63. Sobre los testimonios de griegos «colaboracionistas» con el poder turco (el patriarca Jorge Genadio Escolario o Jorge de Trebisonda) vid. «Fuentes de la caída de Constantinopla», ibidem 567-578.
} 
un imperio pacificando o amansando a los países vencidos y estableciendo lo que Braudel calificó de una especie de pax turcica de la que se hacía eco un anónimo autor francés de 1528.91

\section{EN LA AURORA DE LOS TIEMPOS MODERNOS: ERASMO DE ROTTERDAM}

Los avances otomanos tras la toma de Constantinopla -y, en concreto, el sometimiento de Albania- llevaron a Pío II a un amargo lamento: «No se qué desastres amenazan a Italia».92 Los turcos tomaban, en efecto, en 1480 la ciudad de Otranto, en el extremo sur de la península. ${ }^{33}$ La liberación de la plaza por los Reyes Católicos será saludada por el cronista Lucio Marineo Sículo que se hizo lenguas del socorro enviado al mando de «D. Francisco Henríquez, hermano del almirante Don Alonso y tío del rey Don Fernando».94

Los sucesores de Mahomet II -Bayaceto II (1481-1512) y Selim I (15121520) - no desatendieron los Balcanes y la Europa Central; pero varias treguas con Hungría (de cinco años en 1485 y de diez años en 1495) y paces posteriores con húngaros y venecianos (entre 1502-1503) les llevaron a volcar la atención hacia Siria, Egipto y Persia con éxitos políticos y militares notables. Ello permitió un relativo respiro a los estados europeos en donde, sin embargo, cierta producción literaria siguió advirtiendo del peligro otomano. En 1485, por ejemplo, Giovanni Annio de Viterbo se dio aires de profeta predicando la cruzada contra el turco echando mano de argumentos apocalípticos y astrológicos. Y en 1495, Sebastián Brandt publicó una Historia de Jerusalén desde su fundación por Canaán, hijo de Cam, (hacia el 4.700 a. m) hasta su tiempo. Constituía una llamada a la guerra contra el turco en un tiempo en que los Reyes Católicos tomaron Setenil en su guerra contra los granadinos y en la corte pontificia (22 de noviembre de 1487) Pedro Boscán comparaba a Inocencio IV y Fernando III de Castilla, en cuya época se conquistaron Córdoba y Sevilla, con otro Fernando (el Católico) y otro Inocencio (VIII) que podían presenciar el fin del poder islámico en España. ${ }^{95}$

Esa relativa estabilidad militar se vio decisivamente alterada cuando Solimán el Magnífico tomó al fin Belgrado (1521) y aplastó a los húngaros en Mohacs

91 F. BRAUDEL, El Mediterráneo y el mundo mediterráneo en la época de Felipe II, t. II. México 1976 (sobre la edición francesa de 1963) 19-20.

92 La Europa de mi tiempo... 103.

93 F. BABINGER, Mehmed the Conqueror... 409 y ss.

94 Lucio Marineo Sículo, Vida y hechos de los Reyes Católicos, J. Hidalgo (ed.), Madrid 1943, $55-56$ 54.

95 J. GIL, «El fin del imperio bizantino y su proyección escatológica», Constantinopla 1453... 49-

Hispania Sacra, LXII

126, julio-diciembre 2010, 513-538, ISSN: 0018-215-X 
(28 de agosto de 1526). ${ }^{96}$. El reino danubiano, que hasta entonces actuó de eficaz barrera militar, ${ }^{97}$ vivirá bajo mediatización otomana durante casi dos siglos.

Occidente hubo de tomar de nuevo descarnada conciencia de lo que era un peligro militar tanto en el valle del Danubio como en el Mediterráneo. Hablar del levantamiento del sitio de Viena por Carlos V en 1529, del asedio de Malta en 1565, de la conquista de Chipre por Selim II en 1571 o de la victoria cristiana de Lepanto en esa misma fecha sería llevar las cosas mas allá de lo que es intención de este trabajo.98 Sin embargo no está de más recordar cómo ante la amenaza militar turca hubieron de pronunciarse algunos intelectuales de la época lógicamente influenciados por las opiniones de sus predecesores. En lugar preferente se situará Erasmo de Rotterdam, nacido en los años finales del pontificado de Pío II y ordenado sacerdote en 1492,99 año en el que los Reyes Católicos tomaban Granada; hecho considerado como revancha por la caída de Constantinopla casi medio siglo atrás. ${ }^{100}$

En justicia, Erasmo pasa por ser «el primero de los soberanos espirituales del mundo moderno... (y) el último de los creyentes en un universo cristiano que aboliese las guerras». ${ }^{101}$ La guerra era, a su juicio, un mal inherente a la humanidad que, de darse dentro de la cristiandad -basta con remitirse a las misivas enviadas a los príncipes europeos del momento- tenía el carácter de guerra civil. Las diferencias nacionales no debían ser motivo de discordia como tampoco entre los primeros cristianos tenían que haberlo sido las existentes en Corinto entre los discípulos de Pablo y los de Apolo. ${ }^{102}$

Sincero reformista y sincero católico, Erasmo no dudó, pues estaba dentro de toda una tradición, ${ }^{103}$ en responsabilizar al pontificado de algunos de los en-

\footnotetext{
96 Para las líneas generales de la gran expansión turca en torno a 1500 vid la síntesis de R. MANTRAN, Histoire de la Turquie, París 1975, 48-52.

97 Tras la caída de Constantinopla, la eficaz defensa en el Danubio de dos gobernantes húngaros -el regente Juan de Hunyadi y su hijo el gran rey Matías Corvino- permitió entre 1456 y 1482 levantar el cerco otomano de Belgrado y organizar, incluso, una contraofensiva en Bosnia, Moldavia, Valaquia y Serbia. H. Bogdan, Histoire de la Hongrie, París 1966, 28-31.

${ }^{98}$ Un proceso para cuyo seguimiento sigue siendo útil el magistral estudio debido a la pluma de $\mathrm{F}$. BRAUDEL, El Mediterráneo II, passim

${ }^{99}$ Breve y útil semblanza de Erasmo, Teófanes EGIDO, «Desiderio Erasmo de Rotterdam», Erasmo en España. La recepción del humanismo en el primer renacimiento español. Madrid 2002. 2-7.

${ }^{100}$ Sobre la guerra y conquista de Granada vid, entre otros trabajos de M. A. LADERO el solvente y muy práctico Granada historia de un país islámico. (1232-1571) Madrid 1979, 183-214.

${ }_{101}$ Lucien Febvre, Erasmo, la Contrarreforma y el espíritu moderno. Barcelona 1985 (original de 1957) $78-80$

${ }^{102}$ Citado en M. BATAILlon, Erasmo y España. Estudios sobre la historia espiritual del siglo XVI. México 1986 (Ed. original de 1937) 90.

${ }^{103}$ De la que con toda crudeza se nutrirá en aquellos años Alfonso de Valdés en su diálogo entre Lactancio y el Arcediano. Lamentaba éste el «saco de Roma» por las fuerzas del emperador Carlos V
} 
frentamientos entre príncipes cristianos. Julius exclusus e coelis es el título de una obra redactada en 1513 tras la muerte del papa guerrero Julio II a quien presenta con toda su gloria ante las puertas del Paraíso en donde se le impide entrar. A este escrito antibelicista sucederá, dos años después, el Dulce bellum inexpertis en donde sostiene que la guerra solo resulta agradable para aquellos que la desconocen: «El pueblo funda y construye las ciudades; después la locura de los príncipes las destruye». ${ }^{104}$

Pocas afirmaciones del maestro se han destacado más que la vertida en 1517: «no hay paz tan inicua que no sea preferible a la más justa de las guerras». ${ }^{105}$ Con ello ponía en cuestión la casuística medieval sobre la legitimidad del uso de la fuerza armada en determinados casos. ${ }^{106}$ Las únicas guerras legítimas que el cristiano debe emprender son las que lleva a cabo contra los vicios ya que «cuanto más grave es la enfermedad, mayor cuidado ha de poner la caridad».107 Paralelas a esas guerras espirituales sostenidas por los caballeros, las de los papas sólo serían admisibles -tal y como se recoge en el Julius exclusussi fueran dirigidas contra vicios como la simonía, el orgullo, la ambición, la falta de religión, etc... que son los verdaderos enemigos de la Iglesia. ${ }^{108}$ Erasmo se instalaría con ello en la línea de autores como su amigo Tomás Moro cuyos ciudadanos de Utopía «Abominan de la guerra como de una cosa totalmente bestial y... estiman que nada hay menos glorioso que la fama que de ella se obtiene». 109

Como en casos anteriores, el irenismo de un autor de los primeros tiempos de la modernidad tiene también sus límites. Cuando Erasmo nos habla de paz -incluso a cualquier precio- se está refiriendo, esencialmente, a paz entre gobernantes cristianos. Una idea que en los inicios del XVI confió a la nueva generación de príncipes (Carlos I / V, Francisco I y Enrique VIII) que pronto le

en 1527 aunque eximía del desastre al monarca y responsabilizaba al papa Clemente VII por haber «levantado armas contra él, haciendo lo que no debía, y deshizo la paz, y levantó nueva guerra en la cristiandad». Diálogo de las cosas ocurridas en Roma. José Luis Abellán (ed.), Madrid 1975, 63.

${ }^{104}$ Citado en J. Huizinga, Erasmo. Barcelona 1987 (Original de 1924) 165.

${ }^{105}$ Erasmo de RotTERDAM, «Querella de la paz», Educación del príncipe cristiano. Querella de la paz...131.

${ }^{106}$ Ya en la Educación... escrita en 1516 y dedicada al futuro Carlos V, se recuerdan las desgracias que traen las guerras, incluso las más justas «si es que en puridad existe guerra que pueda llamarse justa», ibid. 103. Erasmo se sentía incompatible con el estilo de Maquiavelo que tomaba las guerras como «ineludibles corolarios del poder político» A. G. Dickens y R. D. Jones, Erasmo el reformador, Madrid 2002, 107

${ }^{107}$ Erasmo de ROTTERDAM, Enquiridion. Manual del caballero cristiano, P. RODRÍGUEZ SANTIDRIÁN (ed.), Madrid 1995, 98. (Obra publicada por primera vez en 1503).

108 Recogido en A. G. Dickens y R. D. Jones, Erasmo... 109.

109 Tomás Moro, «Utopia», en Utopías del Renacimiento, E. Imaz y A. Millares (eds), México 1980, 116 (La obra fue publicada originalmente en 1516).

Hispania Sacra, LXII

126, julio-diciembre 2010, 513-538, ISSN: 0018-215-X 
defraudaron. Las intromisiones políticas de los pontífices tampoco ayudaron; y el estallido luterano y brotes rupturistas coetáneos vinieron a complicar más aún el panorama en el continente. Una invocación del maestro nos recuerda otras precedentes: «Si no nos mueve la piedad, si no nos afecta la calamidad del orbe, muévanos al menos el honor del nombre cristiano. ¿Qué pensamos que dicen de nosotros los turcos y los sarracenos cuando ven que tantos siglos ha no existe armonía alguna entre los príncipes cristianos?».110

\section{¿DE NUEVO El ESPANTAJo OTOMANO?}

Vale remitirse a algunos ejemplos. Jacopo Sadoleto (1477-1547), miembro de la secretaría del papa León X y obispo de Carpentras en el sur de Francia, pronunciaría para Luís XII su discurso Contra Turcos que algunos han comparado con la Querela pacis erasmiana. ${ }^{111}$ En torno a los años de Pavía-Mohacssaco de Roma, Luís Vives, amigo también de Erasmo, escribe su diálogo De Europeae dissidis et bello turcico en donde se hace una sombría descripción de las disensiones entre cristianos y se deposita la confianza en un providencial triunfo imperial. ${ }^{12} \mathrm{El}$ desastre de Mohacs significó, en efecto, un dramático aldabonazo que retumbó en las conciencias de muy destacados humanistas y líderes de opinión del Occidente.

Con posterioridad a una llamada de Lutero para la guerra contra el turco, Erasmo escribe su Consultatio de bello turcico (1530) en donde se acepta la guerra aunque no sin reconocer que la cruzada es impopular por haber derivado frecuentemente en una gran estafa. La guerra contra los turcos puede entenderse aunque siempre -vieja cantinela- sea preferible convertirlos merced a la persuasión. ${ }^{113}$ Con todo, para conducir a los turcos a la verdadera fe, los cristianos tienen que empezar por dar ejemplo; demostrando que son cristianos al rechazar la saña con la que se enfrentan entre ellos. ${ }^{114}$

En resumen: Como años atrás, el miedo al turco era percibido en el primer tercio del siglo XVI como un señuelo para intentar una difícil unidad de los príncipes cristianos. No sólo por el peligro que suponía para su seguridad política. También porque el turco, junto con otras categorías, era presentado como quintaesencia de perversiones de las que había que alejarse.

\footnotetext{
110 Erasmo de RotTERDAM, «Educación del príncipe cristiano»... 106.

111 A. G. Dickens y W. R. D. Jones, Erasmo... 315.

112 M. Bataillon, Erasmo y España... 227-228.

113 Vid. Erasmo de RotTERDAM, «El pretexto de la guerra contra los turcos», Adagios del poder y de la guerra, R. PUig DE LA Bellacasa (ed.) Madrid 2008, 241-246.

114 Erasmo de RotTERDAM, «Querella de la paz»... 139.
} 
Erasmo de Rotterdam a la hora de inculcar al cristiano el rechazo de los vicios llega a poner un curioso ejemplo: «Supón que un hombre es adúltero, blasfemo o turco. Que el cristiano aborrezca al adúltero, no al hombre; desprecie al sacrílego, no al hombre; mate al turco, no al hombre». ${ }^{115}$

En el otro extremo del arco social e intelectual podríamos recurrir a un hombre tan poco sospechoso de connivencia con los poderes establecidos como el reformador radical Tomas Müntzer arquetipo de revolucionario popular para la historiografía marxista. ${ }^{116}$ Pese a arremeter en su vida pública tanto contra católicos como contra luteranos reconoce, como otros reformadores, la existencia de una especial tríada diabólica constituida por «paganos, judíos y turcos».117

\section{A MODO DE CONCLUSIÓN-COROLARIO}

Se ha insistido desde distintas instancias en el papel del miedo ${ }^{118}$ y el rechazo al otro ${ }^{119}$ en la construcción de la sociedad del Occidente Europeo. Ya sea el otro interior: el hereje, el leproso, el judío o el homosexual; o ya sea el exterior: el bárbaro, el árabe, el normando, el mongol o... jel turco!120 La alarma que éste pudiera despertar se manifiesta en dos planos: el de la producción ideológica y el de las relaciones político-militares. En ambos casos las discontinuidades son notables.

Podría decirse que la percepción del turco resulta, en los años en que nos hemos movido, generalmente negativa, incluidas algunas referencias del mismísimo Erasmo. Sobre los niveles de pánico que pudiera causar ya hemos hecho las oportunas observaciones. El miedo / recelo y, en contrapartida, los intentos de comprensión se desarrollaron tanto en el nivel de la reflexión intelectual como en el de la praxis política.

115 Erasmo de RotTerdam, Enquiridion... 198.

116 Un clásico sobre este personaje elaborado desde el materialismo histórico es el de E. BLOCH, Tomas Müntzer, teólogo de la revolución, Madrid 1968 (Edición original de 1922).

117 T. MÜNTZER, «Manifestación explícita de la falsa fe del mundo infiel por mediación del testimonio del Evangelio de Lucas, expuesto a la cristiandad, miserable y digna de compasión para recuerdo de sus errores. Ezequiel cap. 8», en Tratados y sermones. L. Duch (ed.) (autor además de una interesante introducción) Madrid 2001, 156.

118 Vid. para ello Jean Delumeau, La peur en Occident, París 1978.

119 Para este tema en general vid. el interesante trabajo de Eloy BenIto RuANo, De la alteridad en la Historia. Madrid, Real Academia de Historia, 1988.

${ }^{120}$ G. Duby y B. GeremeK, Passions communes. Entretiens avec Ph. Sainteny, París 1992, 35. Vid. también los sugestivos libros, polémicos en algunas de sus interpretaciones, de R. I. MoORE, La formación de una sociedad represora. Poder y disidencia en la Europa occidental, 950-1250, Barcelona 1989, y Josep FonTANA, Europa ante el espejo, Barcelona 1994, especialmente 39-88.

Hispania Sacra, LXII

126, julio-diciembre 2010, 513-538, ISSN: 0018-215-X 
A los enfrentamientos militares sucedía con frecuencia la aplicación de una realpolitik apoyada en la suscripción de treguas entre las dos partes a fin de preservar sus intereses materiales. ${ }^{121} \mathrm{Y}$ frente al ideal de cruzada que en la Edad Moderna mantienen autores como Torcuato Tasso con su Jerusalén liberta$d a,{ }^{122}$ encontramos algunos curiosos ejemplos de islamofilia: por ejemplo, el de esa literatura de tendencia maurófila desarrollada en la península Ibérica que aureola al moro con un conjunto de cualidades que se consideran propias del cristiano; ${ }^{123}$ o el de obras calificadas de erasmitas al estilo de Viaje de Turquía atribuido a Cristóbal de Villalón. ${ }^{124}$

Los estados que fraguan en torno a 1500, sostenía Fernand Braudel, no se fundamentarán sobre el principio medieval de una ciudad-estado: Constantinopla para el imperio bizantino, Barcelona para la Corona de Aragón, Granada para el reino nazarí, sino sobre la base de un estado territorial, no nacional aún, rico en espacio y en hombres. Serán la Francia de los sucesores de Luís XI, la España de los Reyes Católicos o la Turquía de Mahomet II y sus herederos. Sobre esa base surgirán conjuntos más extensos, resultado de acumulaciones, herencias, federaciones o coaliciones de estados particulares que podrían definirse, pese al anacronismo del término, como imperios..$^{125}$

La globalización en todos los terrenos y la esterilidad, cuando no el espíritu suicida de los enfrentamientos entre imperialismos, han abocado a una superación parcial de ese esquema. ${ }^{126}$ Tras el brutal desgaste causado por la Segunda Guerra Mundial, los estados europeos dejaron de ser cabezas de imperios coloniales y se empeñaron en otro proyecto, de muy distinta naturaleza, cuyo punto

${ }^{121}$ Las de 1577 fueron treguas que, según Braudel, contribuirían más a paralizar la iniciativa otomana en el Mediterráneo que el golpe sufrido por la armada turca unos años antes. «Lo que no había logrado completamente Lepanto lo rematará la paz en unos cuantos años. La paz se encargará de matar a la flota turca». F. BRAUDEL, El Mediterráneo. T. II, 656.

122 Cfr. P. García Martín, La péñola y el acero. La idea de cruzada en la España del siglo de Oro, Sevilla 2004.

123 J. M. Delgado, «Maurofilia y maurofobia ¿Dos caras de una misma moneda? Introducción a la antología Narraciones moriscas. Sevilla 1986.

124 Vid. a este respecto los capítulos finales de la citada obra de M. BAtAiLlon, Erasmo y España. No desechar tampoco las viejas consideraciones respecto a las influencias del pensador holandés en España de Marcelino MenÉndez Pelayo, Historia de los heterodoxos españoles. t. I. Madrid 1992, sobre la edición de 1910,939 y ss,

125 F. BRAUDEL, El Mediterráneo t. II, 11-12.

${ }^{126} \mathrm{La}$ crisis de los imperios (continentales o transoceánicos) desde los inicios del siglo XX es, precisamente, el leitmotiv del voluminoso ensayo de N. FERGUSON, La guerra del mundo. Los conflictos del siglo XX y el declive de occidente (1904-1953), Barcelona 2007. Ello no ha obstado para que la expresión «imperio» sea aplicada a las superpotencias surgidas de la derrota de los países del Eje en 1945. Así ha definido el ensayista Sebastian HAFFNER a los dos grandes bloques militares de la Guerra Fría (OTAN y Pacto de Varsovia): imperio americano e imperio ruso. Anotaciones sobre Hitler, Barcelona 2002. 163 . 
de arranque fue el Tratado de Roma de 1957 fundador de la Comunidad Económica Europea que, andando el tiempo, derivaría en la actual Unión Europea.

A día de hoy uno de los interrogantes en torno al futuro de esta construcción es, precisamente, el de las posibilidades de insertarse Turquía en ella. Un estado que, de imperio otomano multinacional y la mayor potencia militar del viejo continente, pasó a ser el «hombre enfermo de Europa» en el siglo XIX, y derivó, tras la derrota en la Gran Guerra de 1914-1918, en un estado-nación homogéneamente turco. A ello contribuyó tanto la revolución republicana kemalista de signo secularizador como la dramática transferencia de poblaciones a uno y otro lado del Egeo.127

Se habla hasta la saciedad de revisar viejos prejuicios sustentados en diferencias religiosas. La tolerancia ha logrado avances importantes para superar enconados malentendidos entre las diversas iglesias cristianas, ${ }^{128}$ pero quedan aún por liquidar otros viejos recelos.

Algunos derivan, aunque sea de forma muy parcial e indirecta, de la interpretación de ese hecho capital que fue 1453.129 En consecuencia, de los prejuicios de naturaleza más o menos turcófoba anclados en el inconsciente colectivo de la vieja Europa. Pese al empuje de la secularización en nuestra sociedad es obvio el peso que aún mantienen tradiciones culturales y clichés mentales que, incluso entre declarados no creyentes, siguen siendo de signo inequívocamente cristiano.

${ }^{127}$ N. Ferguson, La guerra del mundo... 254-263. Un precedente esto último de las tristemente célebres limpiezas étnicas producidas en los Balcanes en los últimos años. La turquización de Constantinopla-Estambul a lo largo del siglo XX eliminó prácticamente la presencia de fuertes minorías étnicoreligiosas que, en conjunto, suponían casi la mitad de la población. Vid. para ello la recreación algo más que literaria de O. PAMUCK, Estambul. Ciudad y recuerdos, Barcelona 2006, 202-207.

${ }^{128}$ Es en ese terreno en el que se acostumbra a plantear la idea de tolerancia. Cfr. Por ejemplo H. Kamen, Los caminos de la tolerancia. Madrid 1967,17-29 para la época aquí tratada.

${ }^{129}$ Para los intelectuales del Imperio Romano de Oriente, la caída de Constantinopla supuso el ineludible final del Imperio Bizantino pero, en el discurrir general de la historia ¿era el final del mundo en el sentido más escatológico? o simplemente ¿el final de $s u$ mundo? P. BÁdENAS, «Los intelectuales bizantinos ante la caída de Constantinopla» en Constantinopla 1453... 166-168. Desde el lado otomano su entrada en la capital suponía la continuidad y perpetuación de la tradición mientras que para los cristianos representaba una dolorosa ruptura. Miguel Ángel BUNES, «Legitimación y deslegitimación de la toma de Constantinopla», ibidem 297-316.

Hispania Sacra, LXII

126, julio-diciembre 2010, 513-538, ISSN: 0018-215-X 